\title{
THE USE OF HPLC METHOD FOR ANALYSIS OF PRAZOSIN HYDROCHLORIDE SUITABLE FOR A CHEMICAL-TOXICOLOGICAL INVESTIGATION
}

\author{
(C) O. Mamina, V. Kabachny
}

Метою дослідження є ідентифікаиія та кількісне визначення празозину гідрохлориду за уніфікованою ВЕРХ-методикою, шзо базується на застосуванні: обернено-фазного варіанту хроматографування, лінійного градієнту та багатоканального УФ-детектування речовин, яке дозволяє отримувати надійні результати досліджень лікарських речовин та їх сумімей у біологічних об 'єктах.

Матеріали та методи. ВЕРХ-хроматографування проводили на мікроколоночному рідинному хроматографі «Міліхром А-02» ("ЕкоНова" Новосибірськ, Росія) в обернено-фазному варіанті. У дослідженні застосовували реактиви кваліфікації «для ВЕРХ» та «ЧДА». Празозину гідрохлорид виділяли з таблеток «Празозин-Ратіофарм» (50 шт.) по 1 мг (Меркле ГмбХ, Німеччина). Чистоту субстанції перевірено методами тонкошарової хроматографії (ТШХ) та УФ-спектроскопї $і$ встановлено відповідність якості щзодо вимог Державної Фармакопеї України (ДФУ).

Результати дослідження. При проведенні ідентифікації встановлено абсолютні часи утримування (15,99-16,12 хв.) та об'єми утримування (1598,5-1611,5 мкл) празозину гідрохлориду, спектральні відношення, межу виявлення препарату у пробі (8,0 мкг/мл або 32,0 нг у пробі), значення коефіиієнтів симетрії піків речовини (0,96-1,04) та коефіцієнтів ємності $(9,44-9,96)$.

Методом найменших квадратів розраховано коефіцієнти регресії градуювального графіку, якому відповідало рівняння прямої $S=0,00134$ С. Коефіиієнт кореляџії дорівнював 0,9993. Розраховано валідаційні характеристики ВЕРХ-методики визначення празозину гідрохлориду: діапазон лінійності (10,0-200,0 мкг/мл), межу кількісного визначення (10,0 мкг/мл або 40 нг у пробі), правильність та точність за результатами кількісного визначення препарату ВЕРX-методом у модельних розчинах $(R S D \overline{\mathrm{X}}=67,9 \%)$. Встановлено, щзо відносна невизначеність середнього результату не перевищувала $\pm 1,89 \%$ при використанні запропонованої методики ВЕРХ-аналізу празозину гідрохлориду у модельних розчинах.

Висновки. Проведено ідентифікацію та кількісне визначення празозину гідрохлориду при використанні уніфікованої ВЕРX-методики, придатної для хіміко-токсикологічного дослідження

Ключові слова: празозину гідрохлорид, ідентифікація, кількісне визначення, ВЕРХ (високоефективна рідинна хроматографія)

\section{Introduction}

Prazosin hydrochloride, like other quinazoline derivatives (doxazosin, alfuzosin and terazosin), belongs to the group of $\alpha_{1}$-adrenoblockers and is used in medical practice for the treatment of arterial hypertension and prostatic hypertrophy $[1,2]$. The drug is used for the effective treatment of post-traumatic stress disorder in children and servicemen who work in difficult conditions $[3,4]$.

For the last 5 years, scientists have focused on the use of prazosin in the treatment posttraumatic stress disorder and alcohol dependence, which is due to the increased probability of suicide attempts in patients, exacerbation of mental disorders. It was found that prazosin improved the results of treatment for alcohol abuse among individuals with posttraumatic stress disorder at different dosing regimens, blocked the stressinduced increase in anxiety that occurs during deprivation of alcohol $[5,6]$.

Existing pharmacological treatment options for nightmares in military veterans associated with hostilities are not effective. As a result of the low profile of side effects and the ability to improve sleep and reduce the nightmares after trauma prazosin has been recommended as an adjuvant therapy [7, 8].

According to the literature data for the period from 2014 to 2017 years in the experiments on animal, scientists were found actual directions of the therapeutic use of prazosin. Development of glioblastoma - an ag- gressive form of primary brain tumor was inhibited when using prazosin [9]. Alpha-adrenergic blockers (prazosin, doxazosin, and terazosin) demonstrated a hepatoprotective effect in the inhibition of elevated catecholamine, which is used in the treatment of acute hepatic insufficiency associated with paracetamol toxicity [10].

To monitor alpha-adrenergic blockers, highly sensitive analytical methods were developed. Quantitative determination of doxazosin mesylate in pharmaceutical preparations and human plasma was carried out using the spectrofluorometric method [11]. Determination of doxazosin and alfuzosin in pharmaceutical preparations, urine samples and plasma samples were carried out according to the procedure of mixed micellar extraction combined with magnetic dispersive $\mu$-solid phase extraction [12]. An analytical method was developed for the study of 11 pharmaceutical preparations (caffeine, prazosin, enalapril, carbamazepine, nifedipine, levonorgestrel, simvastatin, hydrochlorothiazide, gliclazide, diclofenac-Na and mefenamic acid). The method included the steps of: isolation and concentration using solid phase extraction (Oasis HLB), a separation step using high performance liquid chromatography, and a time-of-flight mass spectrometry. The method was used for drinking water, surface water, wastewater treatment plants and wastewater [13].

When applying prazosin, there are possible side effects: headache, weakness, dizziness, insomnia, due to 
active lowering of blood pressure. Destruction of the functions of the digestive tract is manifested by nausea, dry mouth, oral allergic reactions, peripheral edema [1]. In case of overdose or self-medicate with prazosin the cardiovascular system is affected, the activity of the central nervous system is suppressed, respiratory system is broken $[14,15]$.

2. Formulation of the problem in general view, relevance of the topic and its relevance to important scientific or practical issues

The previously developed methods of HPLC analysis of prazosin hydrochloride are distinguished by the use of different chromatographic conditions, which are based on the individual properties of investigated substance. Given that, with insufficient or slow development of the antihypertensive effect, prazosin is combined with diuretics, $\beta$-adrenoblockers, clonidine, or other antihypertensive agents $[1,2]$, an important stage for the further research of medicinal substances and their mixtures in biological objects is the development of a unified HPLC method and the creation of databases by the parameters of identification and quantitative determination of analytes. The results of research on a unified HPLC method can be recommended for the introduction into the practice of the bureau of forensic examination, toxicological centers, clinical laboratories regarding the study of medicinal substances in biological objects.

3. Analysis of recent studies and publications in which a solution of the problem and which draws on the author

Methods of identification and quantification of prazosin hydrochloride by HPLC method in the application of various detection options (UV spectrophotometric [16], mass spectrometry [17, 18], photodiode [18]) were described in the literature.

Analysis of prazosin in various matrices was carried out using different sorbents, composition of moving phases, buffer solutions in isocratic and gradient elution modes.

The detection of the prazosin hydrochloride by the UV spectrophotometric detector at one or two wavelengths limited the use of HPLC-method for the analysis of drug mixtures in biological objects.

Results of the HPLC-study of alpha-adrenergicblocker drug substances in the presence of degradation products were obtained by the use of water-acetonitrilemethanol-glacial acetic acid-diethylamine (25: 35: 40: 1: $0,017)$ as mobile phase for prazosin and terazosin and acetonitrile-water-glacial acetic acid-diethylamine (65: 35: 1: 0,02$)$ for doxazosin in isocratic mode. The detection was performed at $254 \mathrm{~nm}$ [16].

For quantification of prazosin in plasma, urine and whole blood by HPLC method chromatographic conditions were used: column with a nonpolar sorbent Nuclosil 100-10C 18, $10 \mu \mathrm{m}$; the investigated substance was eluted in isocratic mode; the mobile phase-methanolwater-acetonitrile (60: 45: 5, $\mathrm{pH} 3,83)$. The detection was performed at $240 \mathrm{~nm}$ [18].

Identification and quantification of prazosin hydrochloride by HPLC method in the Pharmaceutical formulations were carried out in the following chromato- graphic conditions: column with a nonpolar sorbent Thermo Scientific C18, $5 \mu \mathrm{m}$; the prazosin was eluted in gradient mode: the mobile phase - (A) $0,1 \%$ formic acid in methanol-water (10:90) and (B) acetonitrile-methanol (3: 1). Elution began with $5 \% \mathrm{~B}$ and then linearly increased to $60 \% \mathrm{~B}$ for 3 minutes, additionally increased to $97 \% \mathrm{~B}$ for 3 minutes, and then remained isocratic for 5 minutes [18].

4. Allocation of unsolved parts of the general problem, which is dedicated to the article

The aim of research is the identification and quantification of prazosin hydrochloride according to the unified HPLC method, that based on application:

- reverse-phase chromatography, which is characterized by a high speed of the establishment of sorption equilibrium, the ease and completeness of the desorption of components from a nonpolar sorbent in small volumes of solvent;

- linear gradient at elution of investigated substances, which creates conditions for the exit from the column of all components of the sample in the form of narrow zones;

- multichannel ultraviolet detection of substances that allows you to obtain reliable results for all investigated analytes [19].

\section{Formulation of the aim (tasks) of article}

In order to achieve this purpose, it was necessary to solve the following tasks:

1. To determine the main parameters of retention of prazosin hydrochloride, spectral ratios, and the detection limit of the drug in the sample.

2. To work out the HPLC-method of quantitative determination of prazosin hydrochloride on model solutions using different concentrations of the preparation.

3. To calculate validation characteristics of HPLC-method for determination of prazosin hydrochloride: range of linearity, limit of quantitative determination, correctness and accuracy based on the results of the quantitative determination of the preparation by the HPLC method in model solutions.

6. Statement of the basic material of the study (methods and objects) with the justification of the results

\subsection{Materials and methods}

Prazosin hydrochloride was isolated from tablets Prazosin-Ratiofarm (50 pcs.) of $1 \mathrm{mg}$ (Merkel GmbH \& Co., Germany) as follows: 50 tablets were transferred to a porcelain mortar and triturated to a homogeneous state, then $50 \mathrm{ml}$ of methanol were added and mixed thoroughly. The resulting mixture was filtered through a paper filter in a porcelain cup and evaporated in a water bath at a temperature of not more than $40{ }^{\circ} \mathrm{C}$ to remove the organic solvent; the residue was dried. The purity of the substance was checked by TLC and UV spectroscopy and the quality complies with the requirements of the SPhU.

Reagents for the HPLC-method test corresponded to the "HPLC" qualification: acetonitrile (Sigma-Aldrich Laborchemikallen, GmbH), methanol (Merk, Darmstadt, Germany), water poorly distilled (Merk, Darmstadt, 
Germany). Reagents corresponded qualification "PFA": lithium perchlorate trihydrate (Sigma-Aldrich, USA) perchloric acid (70 \%) (Chimmed, Moscow, Russia).

\subsection{Method of research by the HPLC method}

HPLC chromatography was performed on a microcolonial liquid chromatograph "Milichrome A-02" ("EcoNova", Novosibirsk, Russia) in an reverse-phase variant using a metal column with a nonpolar sorbent Prontosil 120-5C 18 AQ, $5 \mu \mathrm{m}$. The investigated sub R.U.

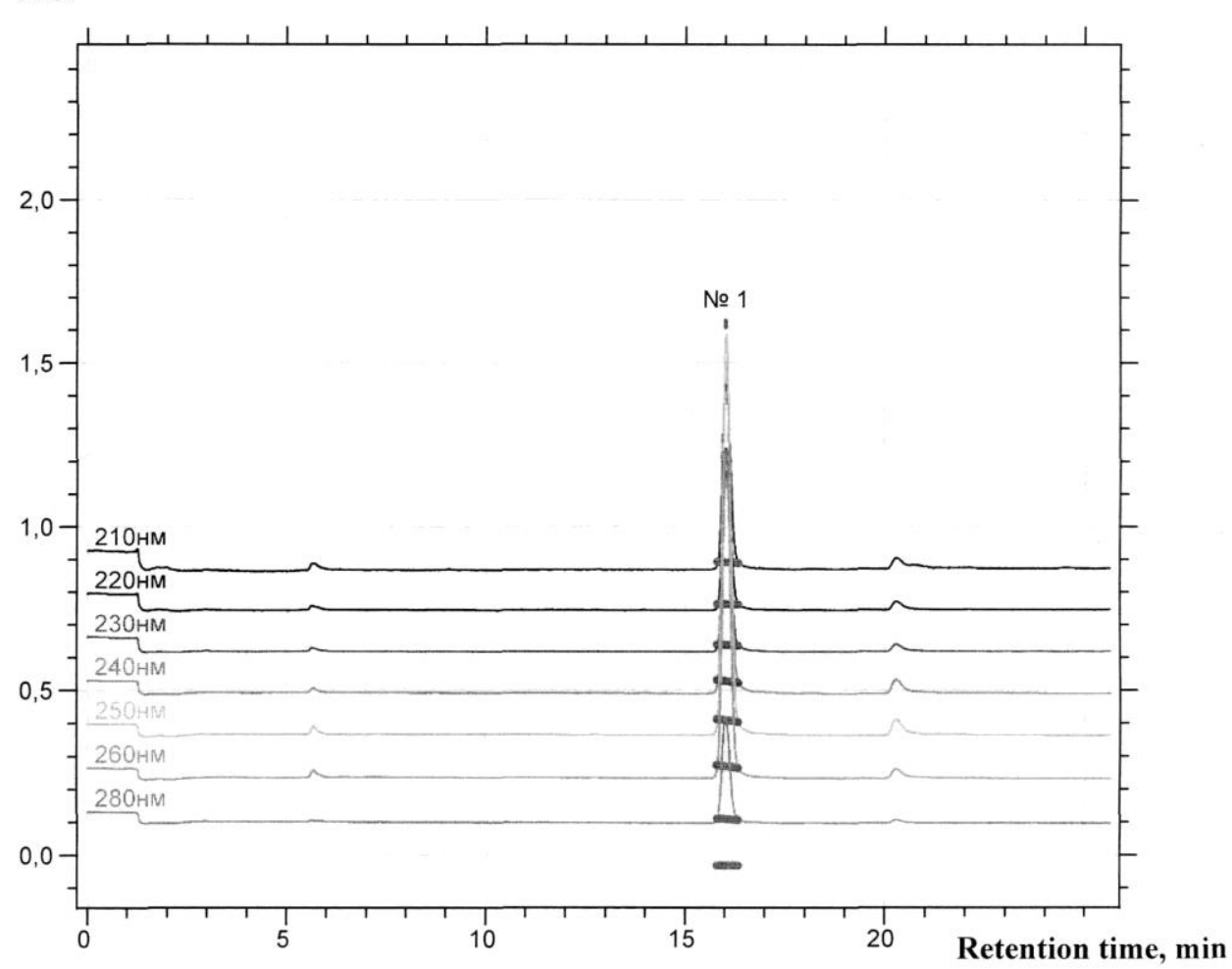

Fig. 1. Chromatogram of prazosin hydrochloride (concentration $-50.0 \mu \mathrm{g} / \mathrm{ml}$ )

Detection was performed using a two-beam multiwave UV spectrophotometer with 8 wavelengths: 210 , 220, 230, 240, 250, 260, 280 and $300 \mathrm{~nm}$, for each value of the wavelength on the substance chromatogram, a corresponding peak with the same retention time was observed, but with different amplitudes, directly proportional to the extinction of the substance.

\subsection{Method of identification of prazosin hy- drochloride by HPLC method \\ $0.025 \mathrm{~g}$ of the investigated substance was placed} in a volumetric flask of $500.0 \mathrm{ml}$, dissolved in $5 \%$ solvent acetonitrile and $95 \%$ buffer solution. The volume of the solution was brought to the mark with a solvent (standard solution at a concentration of $50.0 \mu \mathrm{g} / \mathrm{ml}$ ). In a series of volumetric flasks of $100.0 \mathrm{ml}$ were introduced from the burette $20.0 ; 40.0 ; 60.0$ and $80.0 \mathrm{ml}$ of standard solution and volume of solutions was added to the mark with the appropriate solvent (solutions 1-4 had a concentration of $10.0-40.0 \mu \mathrm{g} / \mathrm{ml}$ respectively). In chromatography, using a unified HPLC method, solutions of prazosin hydrochloride (at least 5 chromatograms for each study) were obtained symmetric, sharp in the shape of the peak, which allowed to calculate the results using the computer program "MultiChrom" ("Ampersend", stances were eluted in linear gradient mode: from eluent A (5\% acetonitrile and $95 \%$ buffer solution $0.2 \mathrm{M}$ solution of lithium perchlorate in $0.005 \mathrm{M}$ solution perchloric acid) to eluent $\mathrm{B}$ (100\% acetonitrile) as during $40 \mathrm{~min}$.

Regeneration of column has been conducted during 2 min with mixture of solvents; the flow rate of the mobile phase has been formed $100 \mu \mathrm{l} / \mathrm{min}$, column temperature $-40{ }^{\circ} \mathrm{C}$; pump pressure $-6.0 \mathrm{MPa}$; injection volume $-4 \mu \mathrm{l}[19,20]$ (Fig. 1).
Moscow, Russia), which was part of the chromatograph.

\subsection{Method of quantitative determination of} prazosin hydrochloride by the method of absolute calibration

$0.10 \mathrm{~g}$ of prazosin hydrochloride was introduced into a volumetric flask of $500.0 \mathrm{ml}$, was dissolved in $5 \%$ acetonitrile and $95 \%$ buffer solution in a solvent, and the volume of the solution was adjusted to the mark by the appropriate solvent (standard solution, concentration $200.0 \mu \mathrm{g} / \mathrm{ml})$.

In a series of volumetric flasks of $100.0 \mathrm{ml}$ were introduced from the burette $5.0 ; 12.5 ; 25.0 ; 37.5 ; 50.0$; $62.5 ; 75.0$ and $87.5 \mathrm{ml}$ of standard solution and volume of solutions was added to the mark with the appropriate solvent (working standard solutions 1 to 8 with concentrations of $10.0 ; 25.0 ; 50.0 ; 75.0 ; 100.0 ; 125.0 ; 150.0$ and $175.0 \mu \mathrm{g} / \mathrm{ml}$, respectively). The results of the HPLC analysis were used to construct the calibration graph in coordinates: $\mathrm{S}, \mathrm{mm}^{2}$ (peak area) $-\mathrm{C}, \mu \mathrm{g} / \mathrm{ml}$ (concentration of solutions of the investigated substance).

\subsection{Research results and their discussion}

The identification of prazosin hydrochloride conducted with using absolute parameters of retention time 
$\left(\mathbf{t}_{R}\right)$ and retention volume $\left(\mathbf{V}_{R}\right)$ (Table 1). Spectral relationships are determined for reliable identification of substance at values of wavelength - from 220 to $300 \mathrm{~nm}$ $\left(\mathbf{S}_{\mathbf{2 2 0 - 3 0 0}} / \mathbf{S}_{\mathbf{2 1 0}}\right)$, which were equal: $0.792,0.916,1.723$, 2.025, 1.508, 0.476, 0.305 .

The suitability of the chromatographic system for HPLC studies of prazosin hydrochloride was con- firmed in determining the coefficients of the symmetry of the peaks of the substance $(\boldsymbol{K} \boldsymbol{s})$ (not exceeding the optimal values of 2.0-2.5) And coefficients of capacity ratio $\left(\boldsymbol{k}^{\prime}\right)$ (were not less than values of $0.5-2.0$ ). It has been found that the limit of detection of prazosin hydrochloride by the HPLC method is $8.0 \mu \mathrm{g} / \mathrm{ml}$ or $32.0 \mathrm{ng}$ in the sample.

Table 1

Parameters of retention, coefficients of the symmetry of the peaks and coefficients of capacity ratio of prazosin hydrochloride $(n=5, P=95 \%)$

\begin{tabular}{|c|c|c|c|c|c|c|c|c|}
\hline \multirow{2}{*}{$\begin{array}{c}\text { Parameters of } \\
\text { identification }\end{array}$} & \multirow{2}{*}{ Parameter values } & \multicolumn{9}{|c|}{ Metrological characteristics } \\
\cline { 3 - 10 } & & $\bar{X}$ & $\mathrm{~S}^{2}$ & $\mathrm{~S}$ & $\mathrm{RSD} \%$ & $\mathrm{~S} \bar{x}$ & $\Delta \bar{x}$ & $\bar{\varepsilon} \%$ \\
\hline $\mathrm{t}_{R, \text { min }}$ & $15.99-16.12$ & 16.05 & 0.028 & 0.052 & 0.33 & 0.023 & 0.065 & 0.40 \\
\hline $\mathrm{V}_{R,} \mu \mathrm{l}$ & $1598.5-1611.5$ & 1605 & 27.5 & 5.24 & 0.33 & 2.34 & 6.50 & 0.41 \\
\hline$K_{s}$ & $0.96-1.04$ & 1.0 & 0.0008 & 0.029 & 2.90 & 0.013 & 0.036 & 3.60 \\
\hline $\mathrm{k}^{\prime}$ & $9.44-9.96$ & 9.70 & 0.043 & 0.21 & 2.13 & 0.092 & 0.26 & 2.65 \\
\hline
\end{tabular}

In the quantitative determination of prazosin hydrochloride, the linearity of the calibration graph in coordinates $\left(\mathrm{S}, \mathrm{mm}^{2}\right)-(\mathrm{C}, \mu \mathrm{g} / \mathrm{ml})$ was observed in the range of concentrations $10.0-200.0 \mu \mathrm{g} / \mathrm{ml}$, which corresponds to the content of prazosin hydrochloride in the sample from $40.0 \mathrm{ng}$ to $800.0 \mathrm{ng}$, respectively. The lower limit of determination of prazosin hydrochloride by the HPLC method was $10.0 \mu \mathrm{g} /$ ml, which corresponds to $40.0 \mathrm{ng}$ in the sample (Fig. 2).

Regression coefficients of the calibration graph $\mathrm{S}={ }_{\mathrm{BC}}+\mathrm{a}$ is calculated using the least squares method (Table 2). The equation of the line $\mathrm{S}=0.00134 \mathrm{C}-$
0.000238 corresponds to the indicated calibration graph. As a result of checking the significance of a free member of the graduation graph equation, it was found that it was slightly different from zero; therefore, an equation of form was used to determine the content of a substance in research objects $\mathrm{S}=0.000134$ $\mathrm{C}$; the correlation coefficient (R) was equal to 0.9993 .

The relative uncertainty of the average result did not exceed $\pm 1.89 \%$ when HPLC analysing of prazosin hydrochloride in model solutions using the proposed method (Table 3).

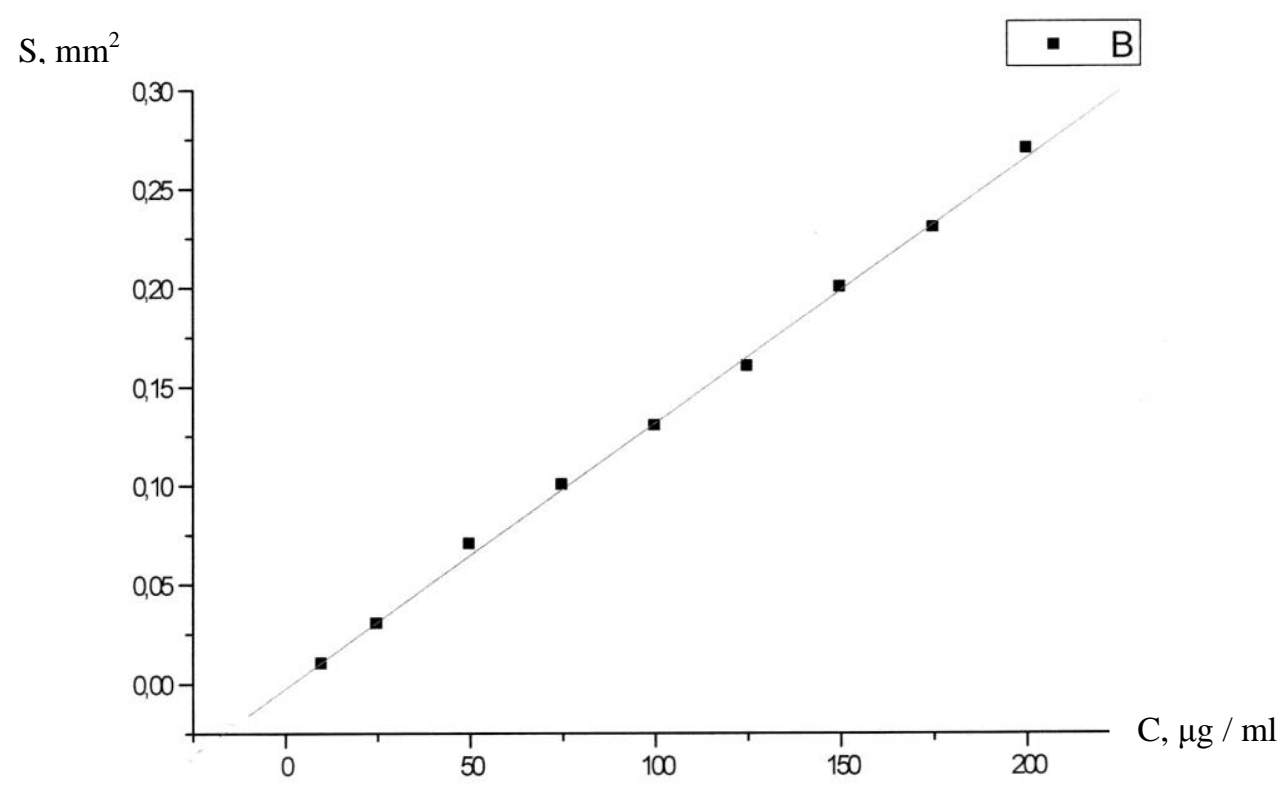

Fig. 2. Calibration graph of quantitative determination of prazosin hydrochloride by HPLC method

Table 2

Coefficients of the regression calibration curve $\mathrm{S}={ }_{\mathrm{B}} \mathrm{C}+\mathrm{a}$ of quantitative determination of prazosin hydrochloride by HPLC method $(n=9, P=95 \%)$

\begin{tabular}{|c|c|c|c|c|c|}
\hline \multicolumn{2}{|c|}{$\begin{array}{c}\text { Coefficients of the regres- } \\
\text { sion calibration curve }\end{array}$} & \multicolumn{2}{|c|}{$\begin{array}{c}\text { Confidence intervals } \\
\text { of regression coefficients }\end{array}$} & $\begin{array}{c}\text { Correlation } \\
\text { coefficient (R) }\end{array}$ & $\begin{array}{c}\text { Interval linearity of calibration } \\
\text { curve (limit of detection, } \mu \mathrm{g} / \mathrm{ml})\end{array}$ \\
\hline $\mathrm{a}$ & $\mathrm{B}$ & $\Delta \mathrm{a}$ & $\Delta \mathrm{B}$ & 0.9993 & $\begin{array}{c}10.0-200.0 \mu \mathrm{g} / \mathrm{ml} \\
10.0 \mu \mathrm{g} / \mathrm{ml}\end{array}$ \\
\hline
\end{tabular}


Results of the quantitative determination of prazosin hydrochloride by HPLC method in model solutions $(\mathrm{n}=5, \mathrm{P}=95 \%)$

\begin{tabular}{|c|c|c|c|c|c|c|}
\hline \multirow{2}{*}{ Introduced substance, $\mu \mathrm{g}$} & \multirow{2}{*}{\multicolumn{2}{|c|}{$\mathrm{S}, \mathrm{mm}^{2}$}} & \multicolumn{4}{|c|}{ Allocated substance } \\
\hline & & & \multicolumn{2}{|c|}{$\mu \mathrm{g}$} & \multicolumn{2}{|c|}{$\%$} \\
\hline 10.0 & \multicolumn{2}{|c|}{0.0104} & \multicolumn{2}{|c|}{10.01} & \multicolumn{2}{|c|}{100.1} \\
\hline 50.0 & \multicolumn{2}{|c|}{0.0697} & \multicolumn{2}{|c|}{49.8} & \multicolumn{2}{|c|}{99.6} \\
\hline 100.0 & \multicolumn{2}{|c|}{0.1307} & \multicolumn{2}{|c|}{100.5} & \multicolumn{2}{|c|}{100.5} \\
\hline 150.0 & \multicolumn{2}{|c|}{0.2001} & \multicolumn{2}{|c|}{100.0} & \multicolumn{2}{|c|}{100.0} \\
\hline 200.0 & \multicolumn{2}{|c|}{0.2670} & \multicolumn{2}{|c|}{197.8} & \multicolumn{2}{|c|}{98.9} \\
\hline $\begin{array}{l}\text { Content of substance in } \\
\text { model solutions, } \%\end{array}$ & \multicolumn{6}{|c|}{ Metrological characteristics, $\%$} \\
\hline \multirow{3}{*}{ 97.9-101.7 } & $\bar{X}$ & $\mathrm{~S}^{2}$ & $\mathrm{~S}$ & $\mathrm{~S} \bar{x}$ & $\Delta \bar{x}$ & $\bar{\varepsilon}$ \\
\hline & 99.8 & 2.32 & 1.52 & 0.68 & 1.89 & 1.89 \\
\hline & \multicolumn{6}{|c|}{$\operatorname{RSD} \bar{x}=67.9 \%, \bar{X} \pm \Delta \bar{x}=99.8 \pm 1.89 \%$} \\
\hline
\end{tabular}

The method of HPLC analysis of prazosin hydrochloride is validated by parameters - the range of linearity, the limits of detection and quantification, rightness and accuracy which based on the results of quantitative determination of prazosin hydrochloride by HPLC method in model solutions ( $\operatorname{RSD} \bar{x}=67.9 \%$ ).

\section{Conclusions}

1. Identification and quantification of prazosin using a unified HPLC method suitable for the study of medicinal substances and their mixtures in biological objects were carried out.

2. Validation characteristics of HPLC-method for determination of prazosin hydrochloride: range of linearity $(10.0-200.0 \mu \mathrm{g} / \mathrm{ml})$, limit of quantitative determination $(10.0 \mu \mathrm{g} / \mathrm{ml}$ or $40 \mathrm{ng}$ of sample), correctness and accuracy, which based on the results of the quantitative determination of the preparation by the HPLC method in model solutions $(\operatorname{RSD} \bar{x}=67.9 \%)$ were calculated.

\section{References}

1. Mashkovskiy, M. D. Lekarstvennyye sredstva [Text] / M. D. Mashkovskiy. - Moscow: Novaya Volna, 2012. - 1216 p.

2. Drogovoz, S. M. Prostatoprotektornaya effektivnost' a1-adrenoblokatorov [Text] / S. M. Drogovoz, V. V. Rossokhin // Provizor. - 2008. - Vol. 11. - P. 23-29.

3. Akinsanya, A. Prazosin in Children and Adolescents With Posttraumatic Stress Disorder Who Have Nightmares [Text] / A. Akinsanya, R. Marwaha, R. R. Tampi // Journal of Clinical Psychopharmacology. - 2017. - Vol. 37, Issue 1. - P. 84-88. doi: 10.1097/jcp.0000000000000638

4. Raskind, M. A. Higher Pretreatment Blood Pressure Is Associated With Greater Posttraumatic Stress Disorder Symptom Reduction in Soldiers Treated With Prazosin [Text] / M. A. Raskind, S. P. Millard, E. C. Petrie, K. Peterson, T. Williams, D. J. Hoff et. al. // Biological Psychiatry. - 2016. - Vol. 80, Issue 10. - P. 736-742. doi: 10.1016/j.biopsych.2016.03.2108

5. Simpson, T. L. A Pilot Trial of Prazosin, an Alpha-1 Adrenergic Antagonist, for Comorbid Alcohol Dependence and Posttraumatic Stress Disorder [Text] / T. L. Simpson, C. A. Malte, B. Dietel, D. Tell, I. Pocock, R. Lyons et. al. // Alcoholism: Clinical and Experimental Research. - 2015. - Vol. 39, Issue 5. - P. 808-817. doi: 10.1111/acer.12703

6. Rasmussen, D. D. Prazosin Prevents Increased Anxiety Behavior That Occurs in Response to Stress During Alcohol Deprivations [Text] / D. D. Rasmussen, C. L. Kincaid, J. C. Froehlich // Alcohol and Alcoholism. - 2016. - Vol. 52, Issue 1. - P. 5-11. doi: 10.1093/alcalc/agw082

7. Breen, A. The efficacy of prazosin for the treatment of posttraumatic stress disorder nightmares in U.S. military veterans [Text] / A. Breen, K. Blankley, J. Fine // Journal of the American Association of Nurse Practitioners. - 2016. - Vol. 29, Issue 2. P. 65-69. doi: 10.1002/2327-6924.12432

8. George, K. C. Meta-analysis of the efficacy and safety of prazosin versus placebo for the treatment of nightmares and sleep disturbances in adults with posttraumatic stress disorder [Text] / K. C. George, L. Kebejian, L. J. Ruth, C. W. T. Miller, S. Himelhoch // Journal of Trauma \& Dissociation. - 2016. - Vol. 17, Issue 4. - P. 494-510. doi: 10.1080/15299732.2016.1141150

9. Assad Kahn, S. The anti-hypertensive drug prazosin inhibits glioblastoma growth via the PKC $\delta$-dependent inhibition of the AKT pathway [Text] / S. Assad Kahn, S. L. Costa, S. Gholamin, R. T. Nitta, L. G. Dubois, M. Feve et. al. // EMBO Molecular Medicine. - 2016. - Vol. 8, Issue 5. - P. 511-526. doi: 10.15252/emmm.201505421

10. Ahmed, J. Effect of adrenergic blockers, carvedilol, prazosin, metoprolol and combination of prazosin and metoprolol on paracetamol-induced hepatotoxicity in rabbits [Text] / J. Ahmed, S. Al-Haroon, M. Zubairi // Indian Journal of Pharmacology. 2014. - Vol. 46, Issue 6. - P. 644-648. doi: 10.4103/0253-7613.144937

11. Omar, M. A. Highly sensitive spectrofluorimetric method for determination of doxazosin through derivatization with fluorescamine; Application to content uniformity testing [Text] / M. A. Omar, M. A. Hammad, B. I. Salman, S. M. Derayea // Spectrochimica Acta Part A: Molecular and Biomolecular Spectroscopy. - 2016. - Vol. 157, Issue 3. - P. 55-60. doi: 10.1016/j.saa.2015.12.012

12. Gao, N. Mixed micelle cloud point-magnetic dispersive $\mu$-solid phase extraction of doxazosin and alfuzosin [Text] / N. Gao, H. Wu, Y. Chang, X. Guo, L. Zhang, L. Du, Y. Fu // Spectrochimica Acta Part A: Molecular and Biomolecular Spectroscopy. - 2015. - Vol. 134, Issue 1. - P. 10-16. doi: 10.1016/j.saa.2014.06.095

13. Al-Qaim, F. F. Multi-residue analytical methodology-based liquid chromatography-time-of-flight-mass spectrometry for the analysis of pharmaceutical residues in surface water and effluents from sewage treatment plants and hospitals [Text] / F. F. Al- 
Qaim, M. P. Abdullah, M. R. Othman, J. Latip, Z. Zakaria // Journal of Chromatography A. - 2014. - Vol. 1345, Issue 6. - P. 139153. doi: 10.1016/j.chroma.2014.04.025

14. Lip, G. Y. Poisoning with anti-hypertensive drugs: alpha-adrenoceptor antagonists [Text] / G. Y. Lip, R. E. Ferner // Journal of Human Hypertension. - 1995. - Vol. 9, Issue 7. - P. 523-526.

15. Clarke, E. J. C. Isolation and Identification of Drugs in Pharmaceuticals, Body Fluids and Postmortem Material [Text] / E. J. C. Clarke. - London: The Pharm. Press, 2011. - 2463 p.

16. Bakshi, M. Validated specific HPLC methods for determination of prazosin, terazosin and doxazosin in the presence of degradation products formed under ICH-recommended stress conditions [Text] / M. Bakshi, T. Ojha, S. Singh // Journal of Pharmaceutical and Biomedical Analysis. - 2004. - Vol. 34, Issue 1. - P. 19-26. doi: 10.1016/j.japna.2003.08.009

17. Lakshmi Narasimham, Y. S. Development and validation of stability indicating UPLC method for the simultaneous determination of beta-blockers and diuretic drugs in pharmaceutical dosage forms [Text] / Y. S. Lakshmi Narasimham, V. D. Barhate // Journal of Chemical Metrology. - 2010. - Vol. 4, Issue 1. - P. 1-20.

18. Shrivastava, A. Brief review on analysis of Prazosin Hydrochloride [Text] / A. Shrivastava // International Journal of Advances in Pharmaceutical Analysis. - 2015. - Vol. 5, Issue 4. - P. 69-75.

19. Baram, G. I. Khromatograf "Milikhrom A-02“. Opredeleniye veshchestv s primeneniyem baz dannykh «VEZHKH-UF» [Text] / G. I. Baram. - Novosibirsk: ZAO Institute of Chromatography, 2005. - 64 p.

20. Kovalska, O. V. Khromatohrafichne doslidzhennya pokhidnykh khinazolinu [Text] / O. V. Kovalska, P. O. Bezugliy, O. O. Mamina // Ukrayinskyi medychnyi almanakh. - 2010. - Vol. 13, Issue 4. - P. 96-97.

Дата надходження рукопису 10.05.2017

Mamina Olena, Doctor of Pharmaceutical Sciences, Professor, Department of Physical and Colloid Chemistry, National Pharmaceutical University, Pushkinska str., 53, Kharkiv, Ukraine, 61002

E-mail: a_mamina@ukr.net

Kabachny Volodimir, Doctor of Pharmaceutical Sciences, Professor, Head of Department, Department of Physical and Colloid Chemistry, National Pharmaceutical University, Pushkinska str., 53, Kharkiv, Ukraine, 61002 E-mail: vikpharm@gmail.com

\title{
UDC 615.074:615.281.9:543.632.562.1 \\ DOI: $10.15587 / 2519-4852.2017 .109254$
}

\section{DEVELOPMENT AND STANDARDIZATION OF TEST SYSTEMS BASED ON FILTER PAPER AND MODIFIED WITH VANILLIN REAGENT}

\author{
(C) V. Prokopetc, O. Zdoryk, V. Georgiyants
}

Реактиви та аналітичні інструменти для проведення експрес-аналізу повинні бути стандартизовані та приведені до вимог Державної Фармакопеї України. Відсутність можливості стандартизаиії газетного паперу істотно ускладнюе використання лігнінової проби як методики експрес-аналізу компонентів екстемпоральних лікарських засобів, що містять в своєму складі первинну ароматичну аміногрупу. Вирішенням даної проблеми може стати розробка тест-систем на основі фільтрувального паперу, модифікованого фармакопейними реактивами.

Мета. Мета дослідження - розробка та в провадження в практику внутрішньоаптечного контролю якості тест-системи на основі фільтрувального паперу, для проведення експрес-аналізу екстемпоральних лікарських засобів, що містять в своїй структурі первинну ароматичну аміногрупу в умовах аптек.

Методи. Метод фізичної іммобілізації; визначення фізичної стабільності тест-систем; економікостатистичні методи (розрахунок вартості); валідація аналітичних методик; статистичні методи обробки експериментальних даних хімічного експерименту.

Результати. Для створення тест-системи був використаний фільтрувального паперу і фармакопейний розчин реактиву ваніліну, можливість застосування тест-системи на практииі досліджувалася за допомогою експрес-аналізу похідних амідів кислоти сульфанілової - сульфащетаміду та сульфатіазолу натрію. Доведено можливість застосування розробленої тест-системи для ідентифікації 5 \% водних розчинів похідних амідів кислоти сульфанілової, встановлена межа виявлення та визначені інтервали ненадійності для методики експрес-аналізу з використанням тест-систем, які склали 5,0-9,0 мг/мл для сульфаиетаміду натрію і 5,3-9,6 мг/мл для сульфатіазолу натрію. Тест-система стабільна протягом 5х місяиів зберігання. Ціна виготовлення 1 тест-системи в умовах аптеки становить 0,34 і 0,16 грн. для першої і наступних партій тест-систем відповідно.

Висновки. Запропонована тест-система є стабільною і доступною до використання в умовах аптек в якості аналітичного інструменту для проведення експрес-аналізу сполук похідних амідів кислоти сульфанілової

Ключові слова: екстемпоральні лікарські засоби, хімічні тест-системи, експрес-аналіз, лігнінова проба, сульфачетамід натрію, сульфатіазол натрію 